\title{
ERA FELIZ Y NO LO SABÍA
}

Verónica Añover ${ }^{1}$

A Silvia

Se rompió, no aguantó. Abandonó. Se desplomó. Se hundió. Se desgarró y no luchó. No pudo. Porque nunca se resignó. Ni aceptó. Ni se conformó. Porque nunca comprendió lo incomprensible y lo inimaginable. Y eso que lo intentó. Pero es que no hubo nada que comprender. Porque la vida no se entiende y la muerte menos aún. No se aferró. Soltó y todo se acabó. Terminaron sus días eternamente largos y eternamente vacíos de sentido. Callaron sus preguntas retóricas lanzadas a la inmensidad muda. Se suspendieron sus llantos y sus lágrimas. Cesaron sus dolores y sus penas. Dejó de arrastrar su destreza y su bombona de oxígeno. Su mente se rindió ante la desgracia y su cuerpo siguió. Sus pulmones se negaron a llenarse de vida. Se quedó vacía por dentro y por fuera. Como el mundo que la rodeaba.

Su hija no la pudo retener. Comprendió que no podía. Que no debía. Respetó el único deseo de su madre. Porque la quería. Porque la entendía. Su marido tampoco pudo salvarla. Porque él más que nadie sabía que era insalvable e irremediable. Porque él también se estaba consumiendo poco a poco. Porque él tampoco existía ya. Sobrevivía. ¿Cómo impedirle a ella que no se dejase morir? Si a él también le faltaban fuerzas para seguir en vida. Pero la inercia... ya se sabe hasta dónde puede llegar. Y ella no llegó porque no quiso. No quiso someterse a la inercia. Ni jugar el juego de la vida. Porque eso no es vida. Para eso es mejor morir.

Era enero, el mes en que nació su hijo. Su vida artificial se apagó. Se extinguió el oxígeno de la bombona y el soplo le faltó. Sintió cómo se encogían sus pulmones y la

\footnotetext{
${ }^{1}$ State University San Marcos. Profesora de español y de francés. California, Estados Unidos. Correo electrónico: vanover@csusm.edu

Recepción: 06/03/2018. Aceptación: 05/04/2018.
} 
asfixia la hizo sentirse eufórica. Por primera vez en muchos años se encontró a gusto, en paz. Pensó en su hija, en su marido, y se fue tranquila porque supo que entenderían. Que se alegrarían. Porque no eran egoístas y habían presenciado su agonía. Habían compartido la tragedia. Y la habían padecido, cada uno a su estilo. Quedaron marcados por el dolor, pero consiguieron sobrellevar la pena. En cambio, ella no pudo. No quiso.

Antes, hacía diez años, era feliz. Pero no lo sabía. Ahora cada día que pasaba le recordaba su infortunio y su desdicha. No nos damos cuenta de lo que tenemos hasta que lo perdemos. Hasta que es demasiado tarde.

Perdió a su hijo en enero. Diez años después ella también se iría, exhalando su último soplo. También en enero. La estación de la muerte.

Diez años antes habían pasado las navidades juntos, los cuatro, tan felices, tan unidos, tan inconscientes. Despidieron el año viejo con risas y alegría. Celebraron el año nuevo brindando con lágrimas amargas. El año se había terminado antes de haber empezado. La vida se paró. Así. De golpe. Veinticuatro horas en el hospital y allí se quedó su cuerpo inerte, a los veinticuatro años. Así. De golpe. Allí mismo se detuvieron los sueños, las ilusiones y las resoluciones. El tiempo quedó fijo en ese día fatídico que le arrebató la vida al hijo tan querido. Como todo hijo. De golpe se desvaneció toda una vida y un futuro brillante por delante. La muerte de un hijo no se supera. La muerte de un hijo no se tolera. No se aguanta. No se puede. Y el mundo se vino abajo.

Enterraron a la madre con su hijo. Bajo tierra quedaron sellados como cuando ella le llevaba en sus entrañas. Como cuando era feliz y no lo sabía.

\section{(c) (i) $\odot$ \\ Esta obra está bajo una licencia de Creative Commons Reconocimiento-NoComercial-}

\section{SinObraDerivada 4.0 Internacional}

